\title{
Effects of wild or mutated inoculants on rye silage and its rumen fermentation indices
}

\author{
Dimas Hand Vidya Paradhipta ${ }^{1,2}$, Young Ho Joo ${ }^{1}$, Hyuk Jun Lee ${ }^{1}$, Seong Shin Lee ${ }^{1}$, \\ Youn Sig Kwak', Ouk Kyu Han², Dong Hyeon Kim1, and Sam Churl Kim,*
}

\footnotetext{
* Corresponding Author: Sam Churl Kim Tel: +82-55-772-1947, Fax: +82-55-772-1949, E-mail: kimsc@gnu.ac.kr
}

1 Division of Applied Life Science (BK21Plus, Institute of Agriculture and Life Science), Gyeongsang National University, Jinju 52828, Korea

2 Faculty of Animal Science, Universitas Gadjah Mada Yogyakarta 55281, Indonesia

${ }^{3}$ Department of Crop Science, Korea National College of Agriculture and Fisheries, Jeonju 54874, Korea

\section{ORCID}

Dimas Hand Vidya Paradhipta

https://orcid.org/0000-0001-7233-469X Young Ho Joo

https://orcid.org/0000-0002-3041-623X Hyuk Jun Lee

https://orcid.org/0000-0003-4766-6742 Seong Shin Lee

https://orcid.org/0000-0002-4872-3705 Youn Sig Kwak

https://orcid.org/0000-0003-2139-1808 Ouk Kyu Han

https://orcid.org/0000-0001-6022-0919

Dong Hyeon Kim

https://orcid.org/0000-0003-0756-8419

Sam Churl Kim

https://orcid.org/0000-0003-3105-0118

Submitted Apr 11, 2019; Revised Jul 5, 2019; Accepted Sept 2, 2019
Objective: This study was conducted to confirm the effects of new inoculants producingantifungal or esterase substances on rye silage and its rumen fermentation indices by comparing wild with mutated types.

Methods: Rye harvested at dough stage was ensiled into $3 \mathrm{~L}$ mini bucket silo (1 kg) for 90 $\mathrm{d}$ in triplicate following: distilled water at $20 \mu \mathrm{L} / \mathrm{g}(\mathrm{CON})$; Lactobacillus brevis 100D8 (AT) and its inactivation of antifungal genes (AT-m) at $1.2 \times 10^{5} \mathrm{cfu} / \mathrm{g}$, respectively; and Leuconostoc holzapfelii $5 \mathrm{H} 4(\mathrm{FD})$ and its inactivation of esterase genes (FD-est) at $1.0 \times 10^{5} \mathrm{cfu} / \mathrm{g}$, respectively. After silo opened, silage was sub-sampled for the analysis of ensiling quality and its rumen fermentation indices.

Results: Among the wild type inoculants (CON vs AT vs FD), FD inoculant had higher $(p<0.05)$ in vitro digestibilities of dry matter and neutral detergent fiber, the total degradable fraction, and total volatile fatty acid in rumen, while AT inoculant had higher $(\mathrm{p}<0.05)$ lactate, acetate, and lactic acid bacteria in silage. Silage $\mathrm{pH}$ and the potentially degradable fraction in rumen increased $(\mathrm{p}<0.05)$ by inactivation of antifungal activity (AT vs AT-m), but lactate, acetate, and lactic acid bacteria of silage decreased $(\mathrm{p}<0.05)$. In silage, acetate increased $(\mathrm{p}<$ $0.05)$ by inactivation of esterase activity (FD vs FD-est) with decreases $(\mathrm{p}<0.05)$ of $\mathrm{pH}$, ammonia-N, lactate, and yeast. Moreover, inactivation of esterase activity clearly decreased $(\mathrm{p}<0.05)$ in vitro digestibilities of dry matter and neutral detergent fiber, the total degradable fraction, and total volatile fatty acid in the rumen.

Conclusion: This study concluded that FD inoculant confirmed esterase activity on rye silage harvested at dough stage, while AT inoculant could not be confirmed with antifungal activity due to the absence of mold in all silages.

Keywords: Antifungal; Esterase; Inoculant; Rye; Silage

\section{INTRODUCTION}

Rye (Secale cereal $L$.) is one of the winter crops used for ruminants to supply the requirement of dietary fiber. Cultivation of rye forage shows a beneficial improvement on soil properties and water quality [1]. Rye has stronger cold tolerance and higher growth rate than other winter forages such as wheat, triticale, and oat [2]. In addition, harvested rye forage at dough stage increases dry matter (DM) yield [3]. However, it could decrease the nutrient digestibility and silage fermentation quality due to increased lignin concentration with reduced water soluble carbohydrate (WSC) content [4].

Application of lactic acid bacteria (LAB) in silage has been widely used to improve the fermentation quality [5] and digestibility of silage [6,7]. Several strains of LAB have abilities of producing antifungal $[8,9]$ and fibrinolytic enzymes $[9,10]$, which could increase the quality of rye silage, especially harvested at the dough stage. An antifungal substance is effec- 
tive to inhibit the growth of undesirable bacteria [8], whereas fibrinolytic enzymes increase the digestibility of silage by hydrolyzing structural carbohydrate (SC) [11]. In addition, esterase enzymes can break down the lignin linkage in plant cells, which is a problem in late harvested forage [11]. In previous studies, application of antifungal-producing inoculant inhibited mold contamination in silage [9], whereas application of esterase-producing inoculant increased fiber digestibility of silage $[10,12]$.

In our previous study, Lactobacillus brevis (L. brevis) 100DB and Leuconostoc holzapfelii (Leuc. holzapfelii) 5H4 were isolated from rye silage and confirmed as antifungal and esteraseproducing bacteria, respectively $[13,14]$. The L. brevis $100 \mathrm{DB}$ had ability to inhibit mycotoxin-producing fungi such as Aspergillus, Penicillium, and Fusarium species [13], while the Leuc. holzapfelii $5 \mathrm{H} 4$ was confirmed to produce esterase enzyme by plate assay [14]. Then, mutant types of L. brevis 100D8 and Leuc. holzapfelii 5H4 were created by inactivated antifungal and esterase excretion genes, respectively.

Therefore, the aim of this study was to confirm the presence of antifungal or esterase activities by both new inoculants on rye silage harvested at dough stage by comparing wild with mutant types, and their effect on rumen fermentation indices.

\section{MATERIALS AND METHODS}

\section{Inoculant}

A complete genome sequence from the wild types of $L$. brevis 100D8 and Leuc. holzapfelii 5H4 were determined by PacBio Sequencing. The lanthionine genes of $L$. brevis 100D8 functioned to regulate the production of antifungal, while esterase genes of Leuc. holzapfelii $5 \mathrm{H} 4$ functioned to regulate the production of esterase enzymes $[13,14]$. The mutated inoculants were created by knockout of those genes in both LABs using clustered regularly interspaced palindromic repeats (CRISPR) and CRIPR-associated nuclease 9 (Cas9) systems. Each mutant was confirmed by polymerase chain reaction, which confirmed the target gene was disturbed and with reduced the sized amplicons. Mutant type of L. brevis 100D8 had no antifungal excretion genes, while mutant type of Leuc. holzapfelii had no esterase excretion gene. This procedure to prepare mutated inoculants with its microbial characteristics was presented in our previous study [14].

\section{Silage production}

The rye forage $(100 \mathrm{~kg})$ was harvested at the dough stage (27.0\% DM) from Gyeongsang National University farm, Jinju, Korea, and then wilted to reach approximately $35.0 \%$ DM. After wilting, the rye was chopped into 3 to $5 \mathrm{~cm}$ lengths. Prior to ensiling, rye forage was separated into five piles and treated with different inoculants: i) control (CON), applied distilled water at $20 \mu \mathrm{L} / \mathrm{g}$; ii) wild type of $L$. brevis 100D8 (AT), applied at $1.2 \times 10^{5}$ colonies forming units (cfu)/g; iii) mutant type of L. brevis 100D8 (AT-m), applied at $1.2 \times 10^{5} \mathrm{cfu} / \mathrm{g}$; iv) wild type of Leuc. holzapfelii 5H4 (FD), applied at $1.0 \times 10^{5}$ cfu/g; and v) mutant type of Leuc. holzapfelii 5H4 (FD-est), applied at $1.0 \times 10^{5} \mathrm{cfu} / \mathrm{g}$. The doses of inoculant were adjusted based on actual count before ensiling. All inoculants were diluted in sterile pure-ultra distilled water at $20 \mathrm{~mL} / \mathrm{kg}$ and sprayed onto rye forage. All treatments were packed into $3 \mathrm{~L}$ plastic bucket silos $(1 \mathrm{~kg})$ and ensiled for $90 \mathrm{~d}$ in triplicate at room temperature $\left(20^{\circ} \mathrm{C}\right)$. The fresh rye forage $(500 \mathrm{~g})$ before ensiling and silage (500 g) after silo opening were sub-sampled for chemical composition and in vitro rumen digestibility analyses. Also, silage (20 g) was sub-sampled and blended with $200 \mathrm{~mL}$ of sterile ultrapure water for $30 \mathrm{~s}$, and then filtered through two layers of cheesecloth to make silage extraction. The fresh silage extraction was used to analyze $\mathrm{pH}$ and microbial counts. After then, silage extraction was stored at $-70^{\circ} \mathrm{C}$ until analyses of ammonia- $\mathrm{N}$, lactate, and volatile fatty acid (VFA).

\section{Chemical compositions}

The sub-sampled forage and silage were dried at $65^{\circ} \mathrm{C}$ for 48 $\mathrm{h}$ and ground to pass 1-mm screen using a cutting mill (Shinmyung Electric Co., Ltd, Gimpo, Korea) for the measurement of chemical compositions and in vitro digestibility for $48 \mathrm{~h}$. The DM concentration was determined by drying sample (about $10 \mathrm{~g}$ ) into the dry oven (OF-22GW, Jeio Tech, Seoul, Korea) at $105^{\circ} \mathrm{C}$ for $24 \mathrm{~h}$. The crude ash (CA) was determined with a muffle furnace at $550^{\circ} \mathrm{C}$ for $5 \mathrm{~h}$. The crude protein (CP) and ether extract (EE) were determined by the producers of Kjeldahl (method 984.13; [15]) using N analyzer (B-324, 412, 435, and 719 S Titrino, BUCHI, Flawil, Switzerland) and Soxhlet (method 920.39; [15]), respectively. The neutral detergent fiber (NDF; method 2002.04; [15]) and acid detergent fiber (ADF; method 973.18; [15]) were determined by using Ankom 200 fiber analyzer (Ankom Technology, Macedon, NY, USA). The hemicellulose (HEMI) was determined by calculating the differences between NDF and ADF. The in vitro $\mathrm{DM}$ digestibility (IVDMD) and in vitro NDF digestibility (IVNDFD) were determined after $48 \mathrm{~h}$ of incubation by method the Tilley and Terry [16] using an Ankom Daisy (Ankom Technology, USA).

\section{Fermentation characteristics of silage}

Silage $\mathrm{pH}$ and ammonia-N were measured using $\mathrm{pH}$ meter (SevenEasy, Mettler Toledo, Greifensee, Switzerland) and the colorimetric method described by Chaney and Marbach [17], respectively. The silage extraction was centrifuged at 5,645 $\times g$ for $15 \mathrm{~min}$ and collected the supernatant for lactate and VFA analyses. The concentrations of lactate and VFA were determined using HPLC (L-2200, Hitachi, Tokyo, Japan) fitted with a UV detector (L-2400; Hitachi, Japan) and a column (Meta- 
carb 87H; Varian, Palo Alto, CA, USA) according to the method described by Muck and Dickerson [18].

\section{Microbial counts}

Silage extract (first dilution) from $90 \mathrm{~d}$ of ensiled silage was continued in several dilutions $\left(10^{-5}\right.$ to $\left.10^{-7}\right)$ to determine microbial counts such as LAB, yeast, and mold. The silage extract was plated in triplicate on selective agar medium. The lactobacilli MRS agar media (MRS; Difco, Detroit, MI, USA) was used for LAB count, and potato dextrose agar media (PDA; Difco, USA) for yeast and mold counts. The MRS agar plates were placed in a $\mathrm{CO} 2$ incubator (Thermo Scientific, Waltham, MA, USA) at $30^{\circ} \mathrm{C}$ for $24 \mathrm{~h}$, while PDA plates were incubated at $28^{\circ} \mathrm{C}$ for $72 \mathrm{~h}$ in an aerobic incubator (Johnsam Corp., Boocheon, Korea). Visible colonies were counted from the plates and the number of cfu was expressed per gram of silage.

\section{In vitro rumen incubation}

The procedure of animal care was approved by animal ethical committee of Gyeongsang National University, Jinju, Korea. The rumen fluid was collected from two non-pregnant cannulated Hanwoo heifers before morning feeding, their diets consisted of rice straw and commercial concentrate mix at $8: 2$ ratio plus vitamin-mineral premix. The collected rumen fluid was composited, and then filtered via two layers of cheesecloth. In vitro medium was made by mixing rumen fluid with anaerobic culture medium at 1:2 ratio described by Adesogan et al [19]. Dried sample at $0.5 \mathrm{~g}$ was put into incubation bottle and $40 \mathrm{~mL}$ of in vitro medium was added. Then the incubation bottle was gassed with $\mathrm{CO}_{2}$ and closed tightly to reach anaerobic condition [19]. Three replications for each treatment were used along with 2 blanks. The bottles were placed into an incubator at $39^{\circ} \mathrm{C}$ for $0,3,6,12,24,48$, and $96 \mathrm{~h}$ to measure gas pressure. Gas pressure was measured by manometer pressure/vacuum gauge monitor (Fisher Scientific, Traceable, Friendswood, TX, USA) to calculate rumen fermentation kinetics. These kinetics were calculated using nonlinear regression procedure of Statistical Analysis Sofware (SAS) [20] to fit with the model of McDonald [21] following:

$$
\mathrm{Y}=\mathrm{A}+\mathrm{B}\left(1-\mathrm{e}^{-\mathrm{c}(\mathrm{t}-\mathrm{L})}\right) \text { for } \mathrm{t}>\mathrm{L}
$$

where $\mathrm{A}$ is the immediately degradable fraction; $\mathrm{B}$ is the potentially degradable fraction; $\mathrm{A}+\mathrm{B}$ is total degradable fraction; $\mathrm{C}$ is the degradation rate of potentially degradable fraction; $\mathrm{L}$ is the lag phase; and $\mathrm{t}$ is time of incubation (h).

After incubation, bottles were opened and transferred to $50 \mathrm{~mL}$ conical tube to separate remains sample and supernatant (in vitro medium) through centrifugation at 2,568 $\times \mathrm{g}$ for 15 min (Supra 21k, Hanil Electric Corporation, Seoul, Korea, with rotor A50S-6C No.6). The supernatant was used to analyze ruminal fermentation indices such as $\mathrm{pH}$, ammonia-N, and VFA. The measurement protocols for $\mathrm{pH}, \mathrm{VFA}$, and ammonia- $\mathrm{N}$ were same as described before.

\section{Statistical analysis}

All collected data were analyzed using one way of analysis of variance through procedure of SAS [20]. The statistical model was $Y_{i j}=\mu+T_{i}+e_{i j}$, where $Y_{i j}=$ response variable, $\mu=$ overall mean, $T_{i}=$ the effect of inoculant $i, e_{i j}=$ error term. This statistical model also determined the effect among wild type (CON vs AT vs FD), and the effect among mutant type (AT vs AT-m or FD vs FD-est) to confirm the antifungal or esterase activity in new inoculants. Mean comparison was performed by Tukey's test. The significant differences were declared at $\mathrm{p}<0.05$.

\section{RESULTS}

\section{Chemical compositions of rye forage and silage}

The concentrations of CP, EE, CA, NDF, ADF, and HEMI of rye forage were $6.48 \%, 1.49 \%, 5.13 \%, 74.4 \%, 46.2 \%$, and $28.2 \%$, respectively (Table 1). The IVDMD and IVNDFD before ensilage were $50.4 \%$ and $38.5 \%$, respectively. After ensiled for $90 \mathrm{~d}$, the inoculant treatments did not affect concentrations of DM, EE, CA, ADF, and HEMI (Table 2). The CP concentration was higher in FD-est silage than $\mathrm{CON}$ and AT-m silages ( $p<0.05 ; 6.85 \%$ vs $6.40 \%$ and $6.41 \%$ ). Silage inoculated with both FD and FD-est produced the lowest NDF concentration, while the highest concentration was with AT-m inoculant ( $\mathrm{p}<0.05 ; 75.4 \%$ and $74.5 \%$ vs $77.9 \%$ ). Silage inoculated with FD produced the higher IVDMD than the other treatments ( $\mathrm{p}<0.05 ; 45.6 \%$ vs $42.2 \%, 42.4 \%, 42.5 \%$, and $42.1 \%$ ). The FD inoculant also produced the highest IVNDFD, while the lowest was by both CON and FD-est inoculants ( $\mathrm{p}<0.05 ; 35.6 \%$ vs $30.6 \%$ and $29.6 \%$ ). Among the wild type inoculants, applied FD inoculant showed higher

Table 1. Chemical compositions and in vitro digestibility of rye forage before ensiled (\%, dry matter)

\begin{tabular}{lc}
\hline Item & Rye forage \\
\hline Dry matter & 35.0 \\
Crude protein & 6.48 \\
Ether extract & 1.49 \\
Crude ash & 5.13 \\
Neutral detergent fiber & 74.4 \\
Acid detergent fiber & 46.2 \\
Hemicellulose & 28.2 \\
In vitro dry matter digestibility ${ }^{1)}$ & 50.4 \\
In vitro neutral detergent fiber digestibility ${ }^{2)}$ & 38.5 \\
\hline 1) In vitro dry matter digestibility incubated with rumen buffer for $48 \mathrm{~h}$. \\
${ }^{2)}$ In vitro neutral detergent fiber digestibility incubated with rumen buffer for $48 \mathrm{~h}$.
\end{tabular}


Table 2. Effects of wild and mutated inoculants on chemical compositions and in vitro digestibility of rye silage ensiled for $90 \mathrm{~d}$ (\%, dry matter)

\begin{tabular}{|c|c|c|c|c|c|c|c|c|c|}
\hline \multirow{2}{*}{ Item } & \multicolumn{5}{|c|}{ Treatment $^{1)}$} & \multirow{2}{*}{ SEM } & \multicolumn{3}{|c|}{ p-value } \\
\hline & CON & AT & AT-m & FD & FD-est & & CON vs AT vs FD & AT vs AT-m & FD vs FD-est \\
\hline Dry matter & 31.9 & 32.5 & 32.2 & 32.6 & 32.8 & 0.919 & 0.666 & 0.557 & 0.871 \\
\hline Crude protein & $6.40^{b}$ & $6.53^{\mathrm{ab}}$ & $6.41^{b}$ & $6.54^{\mathrm{ab}}$ & $6.85^{\mathrm{a}}$ & 0.153 & 0.602 & 0.343 & 0.119 \\
\hline Ether extract & 2.88 & 2.92 & 2.95 & 2.95 & 2.92 & 0.123 & 0.859 & 0.866 & 0.514 \\
\hline Crude ash & 5.92 & 6.29 & 5.88 & 6.31 & 6.12 & 0.163 & 0.018 & 0.024 & 0.259 \\
\hline Neutral detergent fiber & $76.3^{\mathrm{ab}}$ & $76.3^{\mathrm{ab}}$ & $77.9^{\mathrm{a}}$ & $75.4^{b}$ & $74.5^{b}$ & 0.691 & 0.350 & 0.127 & 0.079 \\
\hline Acid detergent fiber & 47.8 & 47.9 & 48.3 & 47.8 & 47.0 & 0.910 & 0.999 & 0.612 & 0.221 \\
\hline Hemicelullose & 28.4 & 28.4 & 29.6 & 27.6 & 27.5 & 0.767 & 0.095 & 0.048 & 0.935 \\
\hline IVDMD & $42.2^{b}$ & $42.4^{b}$ & $42.5^{b}$ & $45.6^{\mathrm{a}}$ & $42.1^{b}$ & 0.750 & 0.009 & 0.937 & 0.005 \\
\hline IVNDFD & $30.6^{b}$ & $32.4^{\mathrm{ab}}$ & $32.7^{\mathrm{ab}}$ & $35.6^{\mathrm{a}}$ & $29.6^{b}$ & 0.962 & 0.011 & 0.818 & 0.008 \\
\hline
\end{tabular}

SEM, standard error of the mean; IVDMD, in vitro dry matter digestibility incubated with rumen buffer for 48 h.; IVNDFD, in vitro neutral detergent fiber digestibility incubated with rumen buffer for $48 \mathrm{~h}$.

1) CON, without inoculation; AT, wild type of Lactobacillus brevis 100D8; AT-m, AT with inactivated antifungal excretion genes; FD, wild type of Leuconostoc holzapfelii 5H4; FD-est, FD with inactivated esterase excretion genes.

a,b Means in the same row with different superscripts differ significantly $(p<0.05)$.

IVDMD $(\mathrm{p}=0.009)$ and IVNDFD $(\mathrm{p}=0.011)$ than CON and AT inoculants. By inactivation of esterase activity, FD-est inoculant had lower IVDMD $(\mathrm{p}=0.005)$ and IVNDFD ( $\mathrm{p}$ $=0.008)$ than FD inoculant. However, AT-m inoculant inactivated antifungal activity had no differences on IVDMD and IVNDFD with AT inoculant.

\section{Fermentation characteristics of silage}

The lowest $\mathrm{pH}$ occurred in FD-est inoculant, followed by AT inoculant and AT-m inoculant, while the highest $\mathrm{pH}$ was recorded in both CON and FD inoculants ( $\mathrm{p}<0.05 ; 4.95$ vs 5.26 vs 5.53 vs 5.72 and 5.73 ; Table 3 ). The concentration of ammonia-N was highest in both $\mathrm{CON}$ and AT inoculants, while the lowest was in FD-est inoculant $(\mathrm{p}<0.05 ; 0.20 \%$ and $0.18 \%$ vs $0.10 \%)$. The highest lactate concentration was found in AT inoculant, followed by CON, AT-m, and FD inoculants, while the lowest concentration was in FD-est inoculant $(\mathrm{p}<0.05$; $2.08 \%$ vs $1.23 \%, 1.42 \%$, and $1.41 \%$ vs $0.73 \%$ ). The highest acetate concentration was in FD-est inoculant, followed by AT inoculant, while the lowest was in $\mathrm{CON}(\mathrm{p}<0.05 ; 1.64 \%$ vs
$0.97 \%$ vs $0.61 \%)$. The acetate concentration of FD silage was similar to CON and AT-m silages. The concentrations of propionate and butyrate were not detected in the present study. Silage inoculated with FD-est had the lowest lactate to acetate ratio, while the highest ratio was in AT inoculant $(\mathrm{p}<0.05$; 0.44 vs 2.14). Among the wild type inoculants, AT inoculant produced lower $\mathrm{pH}(\mathrm{p}=0.001)$, but higher concentrations of lactate $(\mathrm{p}=0.004)$ and acetate $(\mathrm{p}=0.023)$, and lactate to acetate ratio $(\mathrm{p}=0.034)$ than $\mathrm{CON}$ and $\mathrm{FD}$ inoculant. By inactivation of antifungal activity, AT- $\mathrm{m}$ inoculant presented higher $\mathrm{pH}$ $(\mathrm{p}=0.044)$, but lower lactate $(\mathrm{p}=0.011)$ and acetate $(\mathrm{p}=0.009)$ concentrations than AT inoculant. While FD-est inoculant inactivated esterase activity had lower $\mathrm{pH}(\mathrm{p}<0.001)$, concentrations of ammonia $(p=0.001)$ and lactate $(p=0.017)$, and lactate to acetate ratio $(\mathrm{p}=0.002)$, but higher acetate concentration $(\mathrm{p}=0.004)$ than FD inoculant.

\section{Microbial counts of silage}

Silage inoculated with AT inoculant produced the highest LAB count compared to all treatments ( $\mathrm{p}<0.05 ; 7.18$ vs 6.40 ,

Table 3. Effects of wild and mutated inoculants on fermentation characteristics of rye silage ensiled for $90 \mathrm{~d}$

\begin{tabular}{|c|c|c|c|c|c|c|c|c|c|}
\hline \multirow{2}{*}{ Item } & \multicolumn{5}{|c|}{ Treatment $^{1)}$} & \multirow{2}{*}{ SEM } & \multicolumn{3}{|c|}{$p$-value } \\
\hline & CON & AT & AT-m & FD & FD-est & & CON vs AT vs FD & AT vs AT-m & FD vs FD-est \\
\hline $\mathrm{pH}$ & $5.72^{\mathrm{a}}$ & $5.26^{c}$ & $5.53^{b}$ & $5.73^{\mathrm{a}}$ & $4.95^{d}$ & 0.039 & 0.001 & 0.044 & $<0.001$ \\
\hline Ammonia-N (\% DM) & $0.20^{\mathrm{a}}$ & $0.18^{\mathrm{a}}$ & $0.16^{\mathrm{ab}}$ & $0.17^{\mathrm{ab}}$ & $0.10^{b}$ & 0.029 & 0.702 & 0.074 & 0.001 \\
\hline Lactate (\% DM) & $1.23^{b}$ & $2.08^{\mathrm{a}}$ & $1.42^{b}$ & $1.41^{b}$ & $0.73^{c}$ & 0.078 & 0.004 & 0.011 & 0.017 \\
\hline Acetate (\% DM) & $0.61^{d}$ & $0.97^{b}$ & $0.82^{b c}$ & $0.72^{\mathrm{cd}}$ & $1.64^{\mathrm{a}}$ & 0.051 & 0.023 & 0.009 & 0.004 \\
\hline Propionate (\% DM) & ND & ND & ND & ND & ND & - & - & - & - \\
\hline Butyrate (\% DM) & ND & ND & ND & ND & ND & - & - & - & - \\
\hline Lactate to acetate & $1.97^{\mathrm{ab}}$ & $2.14^{\mathrm{a}}$ & $1.46^{\mathrm{b}}$ & $1.89^{\mathrm{ab}}$ & $0.44^{c}$ & 0.142 & 0.034 & 0.085 & 0.002 \\
\hline
\end{tabular}

SEM, standard error of the mean; DM, dry matter; ND, not detected.

1) CON, without inoculation; AT, wild type of Lactobacillus brevis 100D8; AT-m, AT with inactivated antifungal excretion genes; FD, wild type of Leuconostoc holzapfelii 5H4; FD-est, FD with inactivated esterase excretion genes.

a-d Means in the same row with different superscripts differ significantly $(p<0.05)$. 
$6.33,6.15$, and $6.10 \log 10 \mathrm{cfu} / \mathrm{g}$; Table 4). Yeast count was detected in all treatments, except FD-est inoculant $(\mathrm{p}<0.05 ; 6.45$, $6.49,6.56$, and $6.20 \log 10 \mathrm{cfu} / \mathrm{g}$ vs not detected). Inactivation of antifungal activity in AT-m inoculant had lower LAB count ( $p=0.004)$ than in AT inoculant, whereas inactivation of esterase activity in FD-est inoculant had lower yeast growth $(\mathrm{p}<0.001)$ than in FD inoculant.

\section{Rumen fermentation kinetics}

Degradation of fraction A was not affected by inoculant applications (Table 5). Degradations of fraction $B(p<0.05 ; 8.10$ vs $7.00,7.23$, and 7.24 vs $6.01 \mathrm{~mL} / \mathrm{g})$ and $\mathrm{A}+\mathrm{B}(\mathrm{p}<0.05 ; 8.32$ vs 7.07, 7.34, and 7.39 vs $6.15 \mathrm{~mL} / \mathrm{g}$ ) were highest in $\mathrm{FD}$ inoculant, followed by AT, AT-m, and FD-est inoculants, and then in CON. The degradation rate of potentially degradable fraction and lag phase were not affected by selected inoculants. Among the wild type inoculants, silages inoculated with FD produced higher degradations of fraction $A(p=0.012)$, $B(p=0.008)$, and $A+B(p=0.007)$ than CON and AT inoculant. Inactivation of antifungal activity in AT-m inoculant had lower degradation of fraction $B(p=0.037)$ than AT inoculant, whereas inactivation of esterase activity in FD-est inoculant had lower degradations of fraction $B(p=0.029)$ and $A+B(p=0.025)$ than FD inoculant.

\section{Rumen fermentation indices}

Rumen $\mathrm{pH}$ and ammonia-N concentration incubated for 96 $\mathrm{h}$ were not affected by inoculant applications (Table 6). Total VFA concentration was highest in FD inoculant and the lowest was in CON ( $\mathrm{p}<0.05 ; 86.8$ vs $79.0 \mathrm{mM} / \mathrm{dL})$. All silages treated with inoculants presented higher acetate concentration ( $\mathrm{p}<0.05 ; 65.9 \%, 66.1 \%, 66.0 \%$, and $66.6 \%$ vs $62.0 \%$ ) with lower butyrate concentration $(\mathrm{p}<0.05 ; 8.91 \%, 8.69 \%$, $8.95 \%$, and $8.46 \%$ vs $10.9 \%$ ) than CON. The other VFA profiles were not affected by selected inoculants. Among the wild type inoculants, silage inoculated with FD resulted in higher total VFA concentration $(p=0.026)$ than CON and AT inoculant. Inactivation of antifungal did not affect rumen fermentation indices, while inactivation of esterase activity in FD-est inoculant had lower total VFA concentration ( $p$ $=0.005)$ than FD inoculant.

\section{DISCUSSION}

The chemical composition of rye forage in the present study had higher SC such as NDF, ADF, and HEMI concentrations than rye forage harvested at the heading stage (74.4\% vs $60.2 \%$, $46.2 \%$ vs $35.9 \%$, and $28.2 \%$ vs $24.3 \%$, respectively) [22]. This might be due to the different maturity stage, which was harvested at dough stage in the present study. This previous study

Table 4. Effects of wild and mutated inoculants on microbial counts of rye silage ensiled for $90 \mathrm{~d}$ (log10 cfu/g)

\begin{tabular}{|c|c|c|c|c|c|c|c|c|c|}
\hline \multirow{2}{*}{ Item } & \multicolumn{5}{|c|}{ Treatment $^{1)}$} & \multirow{2}{*}{ SEM } & \multicolumn{3}{|c|}{$p$-value } \\
\hline & CON & AT & AT-m & FD & FD-est & & CON vs AT vs FD & AT vs AT-m & FD vs FD-est \\
\hline Lactic acid bacteria & $6.40^{b}$ & $7.18^{\mathrm{a}}$ & $6.33^{b}$ & $6.15^{b}$ & $6.10^{\mathrm{b}}$ & 0.242 & 0.004 & 0.017 & 0.668 \\
\hline Mold & $N D$ & ND & ND & ND & ND & - & - & - & - \\
\hline
\end{tabular}

SEM, standard error of the mean; ND, not detected.

1) CON, without inoculation; AT, wild type of Lactobacillus brevis 100D8; AT-m, AT with inactivated antifungal excretion genes; FD, wild type of Leuconostoc holzapfelii 5H4; FD-est, FD with inactivated esterase excretion genes.

a,b Means in the same row with different superscripts differ significantly $(p<0.05)$.

Table 5. Effects of rye silages treated with wild and mutated inoculants on rumen fermentation kinetics incubated for $96 \mathrm{~h}$

\begin{tabular}{|c|c|c|c|c|c|c|c|c|c|}
\hline \multirow{2}{*}{ Item $^{2)}$} & \multicolumn{5}{|c|}{ Treatment $^{1)}$} & \multirow{2}{*}{ SEM } & \multicolumn{3}{|c|}{ p-value } \\
\hline & CON & AT & AT-m & FD & FD-est & & CON vs AT vs FD & AT vs AT-m & FD vs FD-est \\
\hline $\mathrm{A}(\mathrm{mL} / \mathrm{g} \mathrm{DM})$ & 0.14 & 0.07 & 0.11 & 0.22 & 0.15 & 0.046 & 0.012 & 0.386 & 0.294 \\
\hline$B(\mathrm{~mL} / \mathrm{g} \mathrm{DM})$ & $6.01^{c}$ & $7.00^{b}$ & $7.23^{b}$ & $8.10^{\mathrm{a}}$ & $7.24^{b}$ & 0.255 & 0.008 & 0.037 & 0.029 \\
\hline $\mathrm{A}+\mathrm{B}(\mathrm{mL} / \mathrm{g} \mathrm{DM})$ & $6.15^{c}$ & $7.07^{\mathrm{b}}$ & $7.34^{b}$ & $8.32^{\mathrm{a}}$ & $7.39^{b}$ & 0.194 & 0.007 & 0.088 & 0.025 \\
\hline$C(\% / h)$ & 0.02 & 0.04 & 0.03 & 0.03 & 0.03 & 0.007 & 0.340 & 0.133 & 0.374 \\
\hline$L(h)$ & 20.3 & 21.0 & 21.8 & 20.5 & 21.0 & 0.509 & 0.497 & 0.272 & 0.215 \\
\hline
\end{tabular}

SEM, standard error of the mean; DM, dry matter.

1) CON, without inoculation; AT, wild type of Lactobacillus brevis 100D8; AT-m, AT with inactivated antifungal excretion gene; FD, wild type of Leuconostoc holzapfelii 5H4; FD-est, $F D$ with inactivated excretion gene of esterase.

${ }^{2)} \mathrm{A}$, the immediately degradable fraction; $B$, the potentially degradable fraction; $A+B$, the total degradable fraction; $C$, the degradation rate of potentially degradable fraction; $L$, the lag phase.

${ }^{a-c}$ Means in the same row with different superscripts differ significantly $(p<0.05)$. 
Table 6. Effects of rye silages treated with wild and mutated inoculants on rumen fermentation indices incubated for $96 \mathrm{~h}$

\begin{tabular}{|c|c|c|c|c|c|c|c|c|c|}
\hline \multirow{2}{*}{ Item } & \multicolumn{5}{|c|}{ Treatment $^{1)}$} & \multirow{2}{*}{ SEM } & \multicolumn{3}{|c|}{ p-value } \\
\hline & CON & AT & AT-m & FD & FD-est & & CON vs AT vs FD & AT vs AT-m & FD vs FD-est \\
\hline $\mathrm{pH}$ & 6.39 & 6.37 & 6.41 & 6.41 & 6.42 & 0.025 & 0.313 & 0.228 & 0.435 \\
\hline Ammonia-N (mg/dL) & 21.7 & 20.1 & 20.1 & 21.0 & 22.2 & 1.235 & 0.189 & 1.000 & 0.517 \\
\hline Total VFA (mM/dL) & $79.0^{b}$ & $82.5^{\mathrm{ab}}$ & $81.4^{b}$ & $86.8^{\mathrm{a}}$ & $81.6^{\mathrm{ab}}$ & 1.315 & 0.026 & 0.638 & 0.005 \\
\hline Acetate $(\%)$ & $62.0^{b}$ & $65.9^{\mathrm{a}}$ & $66.1^{\mathrm{a}}$ & $66.0^{\mathrm{a}}$ & $66.6^{a}$ & 0.510 & $<0.001$ & 0.308 & 0.360 \\
\hline Propionate (\%) & 20.4 & 20.4 & 20.7 & 20.4 & 20.4 & 1.154 & 0.601 & 0.938 & 0.389 \\
\hline Iso-butyrate (\%) & 1.46 & 1.11 & 1.06 & 1.04 & 1.05 & 0.227 & 0.173 & 0.736 & 0.173 \\
\hline Butyrate (\%) & $10.9^{\mathrm{a}}$ & $8.91^{\mathrm{b}}$ & $8.69^{b}$ & $8.95^{b}$ & $8.46^{b}$ & 0.218 & $<0.001$ & 0.647 & 0.005 \\
\hline Iso-valerate (\%) & 3.73 & 2.49 & 2.31 & 2.53 & 2.31 & 0.561 & 0.146 & 0.367 & 0.325 \\
\hline Valerate (\%) & 1.51 & 1.19 & 1.11 & 1.08 & 1.18 & 0.208 & 0.148 & 0.810 & 0.184 \\
\hline Acetate to propionate & 3.04 & 3.23 & 3.19 & 3.23 & 3.26 & 0.172 & 0.187 & 0.910 & 0.276 \\
\hline
\end{tabular}

SEM, standard error of the mean; VFA, volatile fatty acid.

1) CON, without inoculation; AT, wild type of Lactobacillus brevis 100D8; AT-m, AT with inactivated antifungal excretion gene; FD, wild type of Leuconostoc holzapfelii 5H4; FD-est, FD with inactivated excretion gene of esterase.

a,b Means in the same row with different superscripts differ significantly $(p<0.05)$.

also reported that different maturity stage affected the chemical compositions of rye forage [22]. After ensiling, CP concentration was highest in FD-est inoculant due to lower proteolysis activity, which agrees with ammonia-N production in the present study (Tables 2, 3). Kim et al [14] had confirmed that FD and FD-est inoculants produced a combination of cellulase and xylanase enzymes, which could degrade SC during ensiling. This might support that inoculation of FD and FDest decreased NDF concentration of rye silage in the present study. In agreement, Lynch et al [6] also reported that NDF concentration of alfalfa silage was lower in mixture of cellulase and xylanase treatment than that of control ( $32.1 \%$ vs $33.5 \%)$.

Silage inoculated with FD increased both IVDMD and IVNDFD of rye silage in the present study. This was affected by FD inoculant application, which produced the esterase enzyme. In general, esterase enzyme is known to hydrolyze the ester linkage of lignin polymer and increase the accessibility of rumen bacteria and other enzymes to degrade lignin complex [11]. The previous studies also confirmed that application of esterase enzyme or esterase-producing bacteria increased nutrient digestibility in rumen $[10,12]$. In the present study, no effects of FD-est inoculant on IVDMD and IVNDFD were caused by the inactivation of esterase activity in this inoculant, which decreased degradation of lignin complex in rye silage. Application of AT inoculant in this study confirmed no effects on IVDMD and IVNDFD, which agreed with the results reported by Joo et al [23].

Silage fermentation quality could be affected by the maturity of forage [4]. Especially, the winter forage will be lignified rapidly with reducing WSC content around at dough stage. With that, silage fermentation quality was decreased [5]. In the present study, rye silage harvested at dough stage had higher $\mathrm{pH}$ with lower organic acid concentration than rye silage harvested at heading or flowering stages [22]. Among all treatments, the lowest $\mathrm{pH}$ in FD-est inoculant was caused by lowest ammonia-N concentration with highest acetate concentration. According to previous studies, it was confirmed that acetate has stronger antifungal activity than lactate [24]. In the present study, higher acetate concentration in FD-est supported the lowest yeast count and ammonia- $\mathrm{N}$ concentration in that silage. None of the studies have been conducted with the mutated inoculant on silage. Therefore, it is difficult to explain why FD-est inoculant produced about two times higher acetate than the others. However, some of the other genes in FD inoculant might accelerate the metabolism pathway to produce acetate due to the removal of esterase excretion genes [25]. Among the wild type inoculants, AT as antifungal-producing inoculant had the highest lactate and acetate concentrations, which also promoted the growth of LAB. Inactivation of antifungal activity in AT-m decrease lactate and acetate productions. Antifungal substances can inhibit the growth of yeast and mold during fermentation [8]. However, yeast count was not affected by inactivation of antifungal activity (AT-m vs AT) in the present study. It could be partially supported by higher $\mathrm{pH}$ (5.53 vs 5.26 ) and lower lactate to acetate ratio (1.46\% vs $2.14 \%$ ) between AT-m vs AT, which it did not inhibit the yeast growth effectively [5].

Several studies had confirmed that esterase enzyme improved the degradation of lignin complex and provide more degradable SC [11]. This evidence could indicate that FD inoculant had higher degradation of fraction $\mathrm{A}, \mathrm{B}$ and $\mathrm{A}+\mathrm{B}$ compared to $\mathrm{CON}$ and all inoculant treatments in the present study. And, it was also supported by an increase of total VFA concentration in the rumen (Table 6) [26]. Inactivation of esterase activity in FD-est inoculant decreased degradable fraction and total VFA in rumen, which also in agreement with decreased IVDMD and IVNDFD in the present study. 
The silage applied with AT inoculant had highest LAB population in the present study, which the degradable carbohydrates were possibly used more for their growth during ensiling (Table 4). It supported partially that result of AT inoculant had the lowest degradation of fraction A among the wild type inoculants. Inactivation of antifungal activity in AT-m inoculant increased the degradation of fraction B. Several antifungal substances can inhibit the gram positive rumen bacteria [27] and reduce fiber digestion [28], which is in agreement with the present study. Nevertheless, the degradation of fraction B by AT inoculant was still higher than CON.

In general, both wild and mutant type of inoculants showed a higher degradable fraction $\mathrm{B}$ or $\mathrm{A}+\mathrm{B}$ than $\mathrm{CON}$ in rumen incubation for $96 \mathrm{~h}$. These results were supported by acetate production in the present study (Table 6), which indicated the high digestibility of SC [29]. Weinberg et al [7] reported that application of LAB with different strains potentially enhanced the rumen digestibility. Contreras-Govea et al [30] also reported that $\mathrm{LAB}$ as silage inoculants could alter rumen digestibility, although the improvement on silage quality was limited.

\section{CONCLUSION}

Rye silage inoculated with wild type of Leuc. holzapfelii 5H4, an esterase-producing inoculant, had improved nutrient digestibility and rumen fermentation indices of compared to L. brevis $100 \mathrm{DB}$. Inactivation of esterase genes in Leuc. holzapfelii $5 \mathrm{H} 4$ clearly decreased the rumen digestibility and fermentation indices of rye silage. Silage inoculated with wild type of L. brevis 100D8 had higher lactate and acetate concentrations than control and Leuc. holzapfelii 5H4. Inactivation of antifungal genes in L. brevis 100D8 decreased lactate and acetate concentrations of silage but had no effect on yeast count. This study confirmed that wild type of Leuc. holzapfelii $5 \mathrm{H} 4$ produced esterase activity in rye silage harvested at dough stage, while antifungal activity in L. brevis 100DB could not be confirmed due to the absence of mold in all silages.

\section{CONFLICT OF INTEREST}

We certify that there is no conflict of interest with any financial organization regarding the material discussed in the manuscript.

\section{ACKNOWLEDGMENTS}

This research was performed with the support of "Cooperative Research Program for Agriculture Science \& Technology Development (Project No. PJ011012032017)" Rural Development Administration, Korea.

\section{REFERENCES}

1. Moore EB, Wiedenhoeft MH, Kaspar TC, Cambardella CA. Rye cover crop effects on soil quality in no-till corn silagesoybean cropping systems. Soil Sci Soc Am J 2014;78:96876. https://doi.org/10.2136/sssaj2013.09.0401

2. Bruckner PL, Reymer PL. factors influencing species and cultivar choice of small grains for winter forage. J Prod Agric 1990;3:349-55. https://doi.org/10.2134/jpa1990.0349

3. Lee BS, Kim JD, Kwon CH, Chung KW. Effect of variety and harvest date on the forage production and quality in winter rye. J Anim Sci Technol 2004;46:227-34. https://doi.org/10. 5187/JAST.2004.46.2.227

4. Filya I. Nutritive value and aerobic stability of whole crop maize silage harvested at four stages of maturity. Anim Feed Sci Technol 2004;116:141-50. https://doi.org/10.1016/j.anifeedsci. 2004.06.003

5. McDonald P, Henderson AR, Heron SJE. The biochemistry of silage, 2nd ed. Bucks, UK: Chalcombe Publ; 1991.

6. Lynch JP, Prema D, Van Hamme JD, Church JS, Beauchemin KA. Fiber degradability, chemical composition and conservation characteristics of alfalfa haylage ensiled with exogenous fibrolytic enzymes and a ferulic acid esterase-producing inoculant. Can J Anim Sci 2014;94:697-704. https://doi.org/10.4141/ cjas-2014-086

7. Weinberg ZG, Shatz O, Chen Y, et al. Effect of lactic acid bacteria inoculants on in vitro digestibility of wheat and corn silage. J Dairy Sci 2007;90:4754-62. https://doi.org/10.3168/ jds.2007-0176

8. Dalié DKD, Deschamps AM, Richard-Forget F. Lactic acid bacteria-potential for control of mould growth and mycotoxins: a review. Food Control 2010;21:370-80. https://doi.org/10. 1016/j.foodcont.2009.07.011

9. Kim HS, Han OK, Kim SC, Kim MJ, Kwak YS. Screening and investigation Lactobacillius spp. to improve Secale cereale silage quality. Anim Sci J 2017;88:1538-46. https://doi.org/10.1111/ asj.12781

10. Kang TW, Adesogan AT, Kim SC, Lee SS. Effects of an esteraseproducing inoculant on fermentation, aerobic stability, and neutral detergent fiber digestibility of corn silage. J Dairy Sci 2009;92:732-8. https://doi.org/10.3168/jds.2007-0780

11.Adesogan AT, Ma ZX, Romero JJ, Arriola KG. Ruminant Nutrition Symposium: Improving cell wall digestion and animal performance with fibrolytic enzymes. J Anim Sci 2014;92:1317-30. https://doi.org/10.2527/jas.2013-7273

12. Arriola KG, Kim SC, Staples CR, Adesogan AT. Effect of fibrolytic enzyme application to low- and high-concentrate diets on the performance of lactating dairy cattle. J Dairy Sci 2011;94: 832-41. https://doi.org/10.3168/jds.2010-3424

13. Kim MJ, Kim HS, Kim SC, Kwak YS. Complete genome sequence of lanthionine-producing Lactobacillus brevis strain 100D8, generated by PacBio sequencing. Microbiol Resour 
Announc 2018;7:e1220-18. https://doi.org/10.1128/MRA. 01220-18

14. Kim HS, Han OK, Kwak YS. Complete genome sequence and functional study of the fibrinolytic enzyme-producing bacterium Leuconostoc holzapfelii 5H4, a silage probiotic. J Genomics 2017;5:32-5. https://doi.org/10.7150/jgen.19407

15. AOAC. Official methods of analysis. 18th edn. Association of Official Analytical Chemists, Washington DC, USA: AOAC International; 2005.

16. Tilley JMA, Terry RA. A two-stage technique for the in vitro digestion of forage crops. J Br Grassl Soc 1963;18:104-11. https://doi.org/10.1111/j.1365-2494.1963.tb00335.x

17. Chaney AL, Marbach EP. Modified reagents for determination of urea and ammonia. Clin Chem 1962;8:130-2.

18. Muck RE, Dickerson JT. Storage temperature effects on proteolysis in alfalfa silage. Trans ASASE 1988;31:1005-9. https:// doi.org/10.13031/2013.30813

19. Adesogan AT, Krueger NK, Kim SC. A novel, wireless, automated system for measuring fermentation gas production kinetics of feeds and its application to feed characterization. Anim Feed Sci Technol 2005;123-4:211-23. https://doi.org/ 10.1016/j.anifeedsci.2005.04.058

20.SAS Institute Inc. SAS/STAT user's guide: Version 9. Cary, NC, USA: SAS Institute Inc.; 2002.

21.McDonald I. A revised model for the estimation of protein degradability in the rumen. J Agric Sci 1981;96:251-2. https:// doi.org/10.1017/S0021859600032081

22. Kim JG, Chung ES, Seo S, et al. Effects of maturity at harvest and wilting days on quality of round baled rye silage. AsianAustralas J Anim Sci 2001;14:1233-7. https://doi.org/10.5713/ ajas.2001.1233

23.Joo YH, Kim DH, Paradhipta DHV, et al. Effect of microbial inoculants on fermentation quality and aerobic stability of sweet potato vine silage. Asian-Australas J Anim Sci 2018;31: 1897-902. https://doi.org/10.5713/ajas.18.0264

24.Danner H, Holzer M, Mayrhuber E, Braun R. Acetic acid increases stability of silage under aerobic conditions. Appl Environ Microbiol 2003;69:562-7. https://doi.org/10.1128/ AEM.69.1.562-567.2003

25. Kim J, Kim JG, Park BK, et al. Identification of genes for biosynthesis of antibacterial compound from Pseudomonas fluorescens $\mathrm{Bl6}$, and its activity against Ralstonia solanacearum. J Microbiol Biotechnol 2003;13:292-300.

26. Hobson PN, Stewart CS. The rumen microbial ecosystem, 2nd edition. London, UK: Blackie Academic and Professional; 1997.

27. Wells JE, Krause DO, Callaway TR, Russell JB. A bacteriocinmediated antagonism by ruminal lactobacilli against Streptococcus bovis. FEMS Microbiol Ecol 1997;22:237-43. https:// doi.org/10.1111/j.1574-6941.1997.tb00376.x

28. Piwonka EJ, Firkins JL. Effect of glucose fermentation on fiber digestion by ruminal microorganism in vitro. J Dairy Sci 1995; 79:2196-206. https://doi.org/10.3168/jds.S0022-0302(96) 76596-7

29.Lee M, Jeong S, Seo J, Seo S. Changes in the ruminal fermentation and bacterial community structure by a sudden change to a high-concentrate diet in Korean domestic ruminants. Asian-Australas J Anim Sci 2019;32:92-102. https://doi.org/ 10.5713/ajas. 18.0262

30.Contreras-Govea FE, Muck RE, Mertens DR, Weimer PJ. Microbial inoculant effects on silage and in vitro ruminal fermentation, and microbial biomass estimation for alfalfa, bmr corn, and corn silages. Anim Feed Sci Technol 2011;163: 2-10. https://doi.org/10.1016/j.anifeedsci.2010.09.015 